\title{
Geological characteristics of underground gas storages from Romania
}

\author{
Isabela FALK* \\ Fugro-Jason, Buchholzerstr.98-100, 30655 Hannover, Germany
}

Received July 2006; accepted November 2006

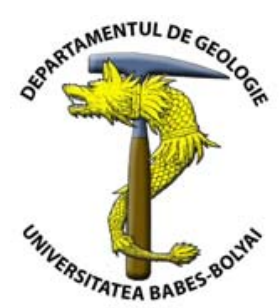

\begin{abstract}
Underground gas storages from Romania are located in south Romania (in the Moesian Platform) and in Transylvanian Basin. They are converted from depleted gas reservoirs. Those from south have bigger capacity because the reservoirs are thick and stratiform, consisting of unconsolidated sand, with high porosity and permeability. The Transylvanian storages have smaller capacity because the layers are thinner, consisting of interbedded sandstones, silts and marls, with many lithological and facies variations, lower porosities and permeabilities. Geology of the reservoir has to be well known before constructing a deposit. Most important parameters are: depth of the reservoir, thickness, porosity, permeability, pore volume, structural model, tectonics, stratigraphic and lithological variations, type of aquifer, etc.
\end{abstract}

Key words: UGS, depleted reservoirs, geological parameters, Romania

\section{INTRODUCTION}

Because of continuing decrease of national gas production and increase of the import gas price, the necessity of creating underground gas storages (UGS) became a priority for the Romanian gas industry.

The first UGS was created in 1978 and in present there are eight operating UGS and one in project. Their location is chosen considering wintertime consumption of different regions of the country.

The region with the highest demand in wintertime is the Bucharest area, where are located three storages: Urziceni, Bilciureşti and Bălăceanca-Postăvari. One UGS was created recently near Craiova: Simnic-Gherceşti. There are also four storages in Transylvania, with smaller capacity: TârguMureş, Sărmăşel, Nadeş-Prod and Cetatea de Baltă. Other region that needs an UGS is Moldova, where a newly proposed storage is located.

To design an UGS it should exist first an adequate transportation system to bring gas to the deposit and to distribute it to the consumers. It is also necessary to have surface facilities and compressors for injection.

UGS from Romania are located in depleted gas reservoirs. These kinds of reservoirs are preferred worldwide because they already have production wells that can be used, surface facilities and pipelines for transportation.

UGS can be located also in depleted oil fields, aquifers, salt rock caverns and depleted mines. The distribution of these types of storages in the world can be seen in Fig.1.

Most of the UGS are situated in North America (USA and Canada), the second place is Russia and the third is Western Europe (Italy, France and Germany) (Grigoraş, 2002).

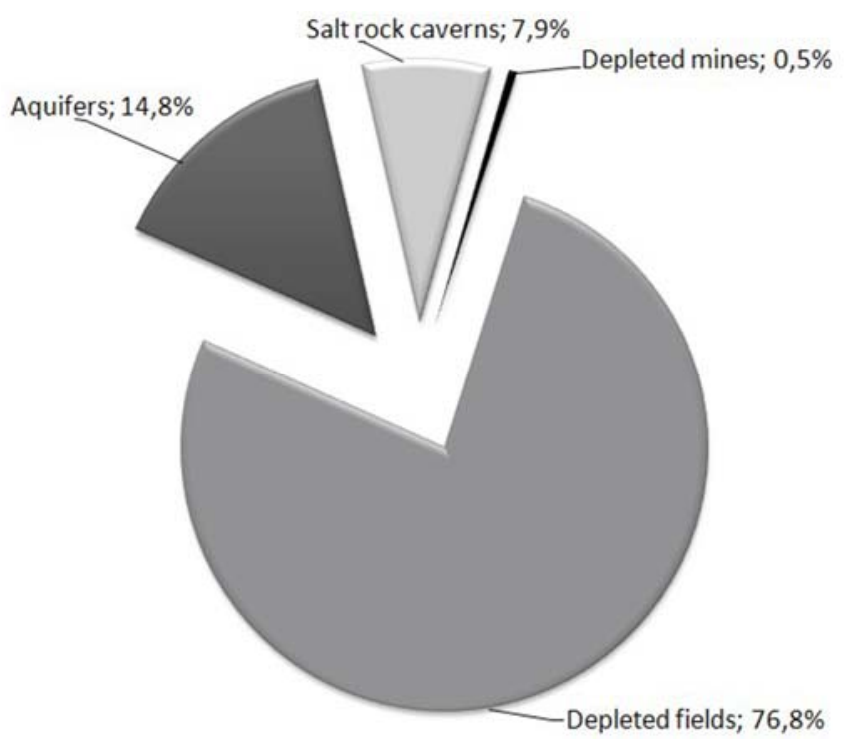

Fig. 1. World distribution of UGS deposit types.

\section{GEOLOGICAL CHARACTERS OF UGS}

Several geological parameters should be considered when choosing a reservoir to transform it in a deposit. These parameters are: thickness, porosity, permeability, the structural model, tectonics, stratigraphy and lithological variations, type of aquifer etc.

Other important criteria for creating an UGS deposits are: pore volume (product between reservoir volume and effective porosity), depth of the reservoir, number of injection and producing wells, compressors, transportation system, costs and economical feasibility. 
Depth is important when choosing a reservoir for UGS because drilling costs for new wells will be higher and pressure decrease along the tubing will be higher. In addition, the injection pressure would have to be higher if the reservoir is deeper. This is why specialists are looking for shallower reservoirs.

Thickness, along with surface area, determines the bulk volume of the reservoir, which determines the capacity of the storage. If the reservoir is not thick enough, one solution could be to use more superposed reservoirs together, for the same deposit.

Thickness is important for the well productivity. The thicker is the layer, the longer will be the perforated interval and, consequently, the higher will be the productivity of the well. Using horizontal or deviated wells, this problem can be solved, but the drilling cost will be higher.

Porosity is very important for the productivity of the reservoir. A good reservoir always has a high porosity. Permeability, which is also very important for the productivity of the reservoir, is closely related to porosity. These two petrophysical parameters of the reservoir are very important for a quick withdrawal of the injected gas from the UGS in wintertime, when the demand is high.

Structural model and tectonics of the reservoir have to be well known because the closure of the trap has to be very good, to prevent the gas losses from the deposit. Usually deposits are created in anticlines and well-closed monoclines. If the reservoirs are faulted, the permeability of the faults should be well known in order to control the fluid and pressure distribution inside the reservoir. Fractures and their permeability are also very important.

Stratigraphy and lithology of the reservoir should also be well known. Their variation can determine changes of properties as porosity, permeability and saturation and, consequently, pressure variations in the time of injection and production processes. Well-consolidated rocks, like sandstones, are preferred instead of unconsolidated deposits (sand). If the sediments are not well consolidated, because of high pressure variations in the injection-production process, the wells could sand up and diminish the production.

Aquifer can be more or less active in the reservoir. The less active it is, the lower will be the injection pressures and the risk of pore volume decrease in time will diminish.

To control all these parameters of the reservoir, serious geologic investigations have to be carried out. Seismic, well bore geophysical investigations and core analysis have to be established in order to determine all the parameters and their variations. The amount of investigations depends on how complex and heterogeneous the reservoir is.

\section{UGS IN ROMANIA}

Storages from Romania can be subdivided in two categories depending on their geographical position and geological characteristics: 1. deposits from southern Romania, 2. deposits from Transylvania.

\section{UGS from southern Romania.}

They are all located in the Moesian Platform. These reservoirs are formed in faulted monoclines, except for Simnic-Gherceşti, which is located in a large anticline structure.
They are all thick deposits of unconsolidated or weakly consolidated sands with marl and silt intercalations (Fig. 2). Some of the reservoirs are lithologically delimited because of facies variations. The predominant depositional environment was alluvial fan. The age of the reservoirs is Meotian and Pontian.

Depth of the deposits varies between $300 \mathrm{~m}$ and $2000 \mathrm{~m}$. Net thickness of the reservoir is up to $32 \mathrm{~m}$. Mean porosities vary between $25-30 \%$ and mean permeabilities between 20 1000 mD. (S.N.G.N. Romgaz S.A., 1998, 2003, 2005; S.C. Gaz Consult S.A., 2005). These are good parameters for an UGS because they allow a good flow in the reservoir, a good pressure distribution, an easy injection and an easy recovery of the injected gas.

Because of the great thickness, good porosity and large surface area, these deposits have a big capacity, which can be developed in time, following the market demand.

The reservoirs have a water-drive production mechanism, which is inconvenient because the pore volume is reduced in time. The injection pressures have to be higher in order to prevent the water influx in the deposit. Other problem is the lithology of the reservoirs. The unconsolidated sand can cause sanding up of the wells and, in order to prevent this phenomenon, special filters have to be used in wells, resulting in supplementary costs.

\section{UGS from Transylvania.}

Sedimentation from this region is very heterogeneous, with many facies and lithological changes. The gas reservoirs are located in Miocene deposits, characterized by molasse-type sedimentation, with thin layers of sand and sandstones, alternating with marl, clay and silt layers. Facies types vary from deep-water turbidites and alluvial fans to delta systems. As documented by core data analysis a poor sorting of the sediments can often be recognized resulting in poor reservoir properties, especially in low permeability.

Because the layers are not thick enough, often several superposed layers are used together to create one UGS (Fig. 3).

Depth of the Transylvanian storages varies from $450 \mathrm{~m}$ to $1300 \mathrm{~m}$. Total net thickness of the reservoirs can be up to $25 \mathrm{~m}$. Mean porosity varies between $17-22 \%$, and the mean permeability between 10-70 mD. (C.C.I.T.G.M. Romgaz R.A., 1996; S.C. Amgaz S.A., 2004; S.N.G.N. Romgaz S.A., 2001)

The aquifers are usually limited in this region and waterdrive is not a problem. Consequently, injection pressures do not have to be very high. These UGS have a smaller capacity because the properties of the reservoirs are not so good. Other reason is that more injection-production wells have to be drilled, because of low permeabilities, which mean higher costs.

\section{CONCLUSIONS}

In order to become UGS, the reservoirs should be located as close as possible to the consumption region, should have a good structural and stratigraphic closure, good effective porosity and permeability and relatively low depth.

The favorites are the depleted gas reservoirs, without water-drive, because they need the minimum investment. Surface facilities, compressors and a good transportation system are also needed. 


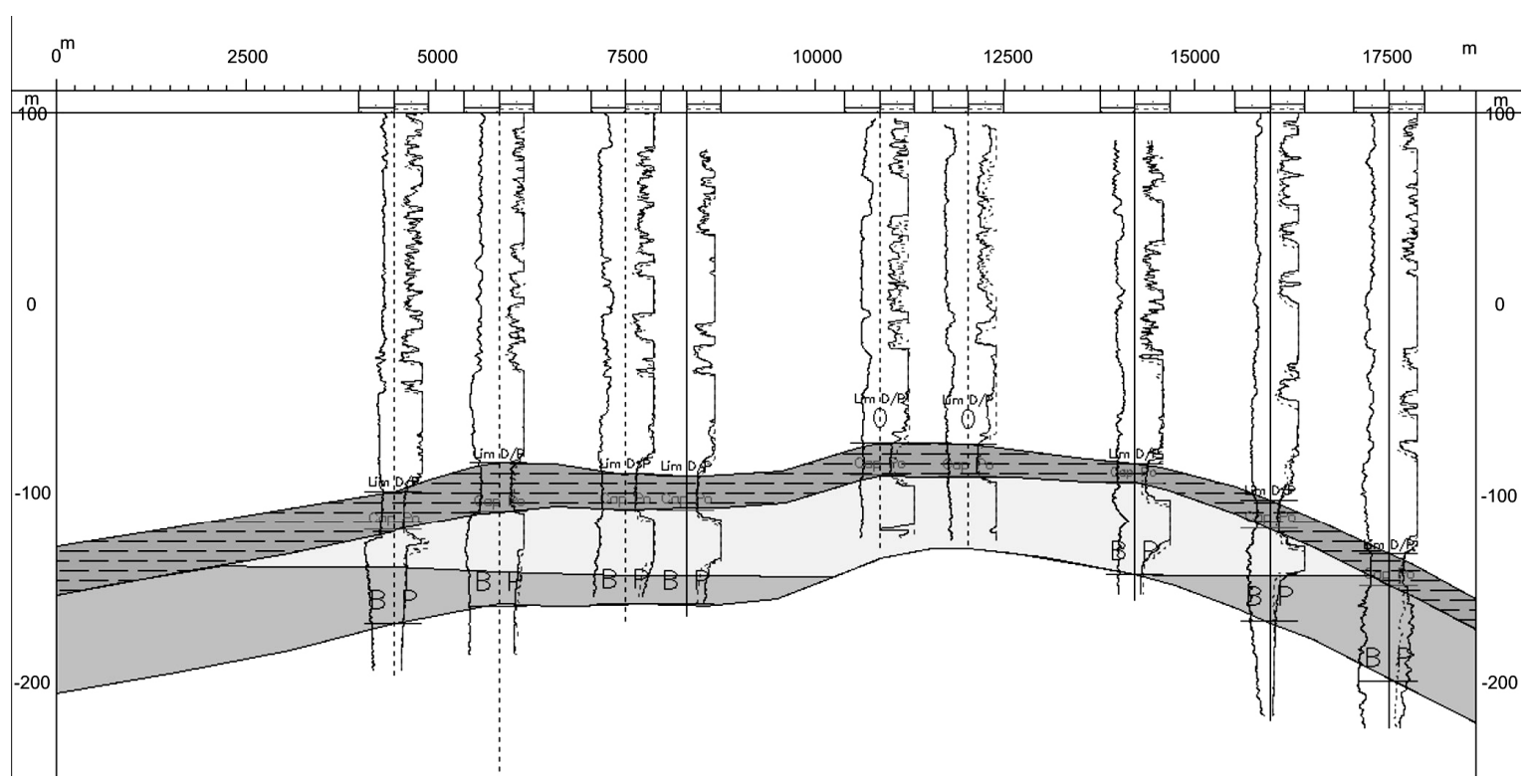

Fig. 2. Cross-section from a southern Romanian UGS.

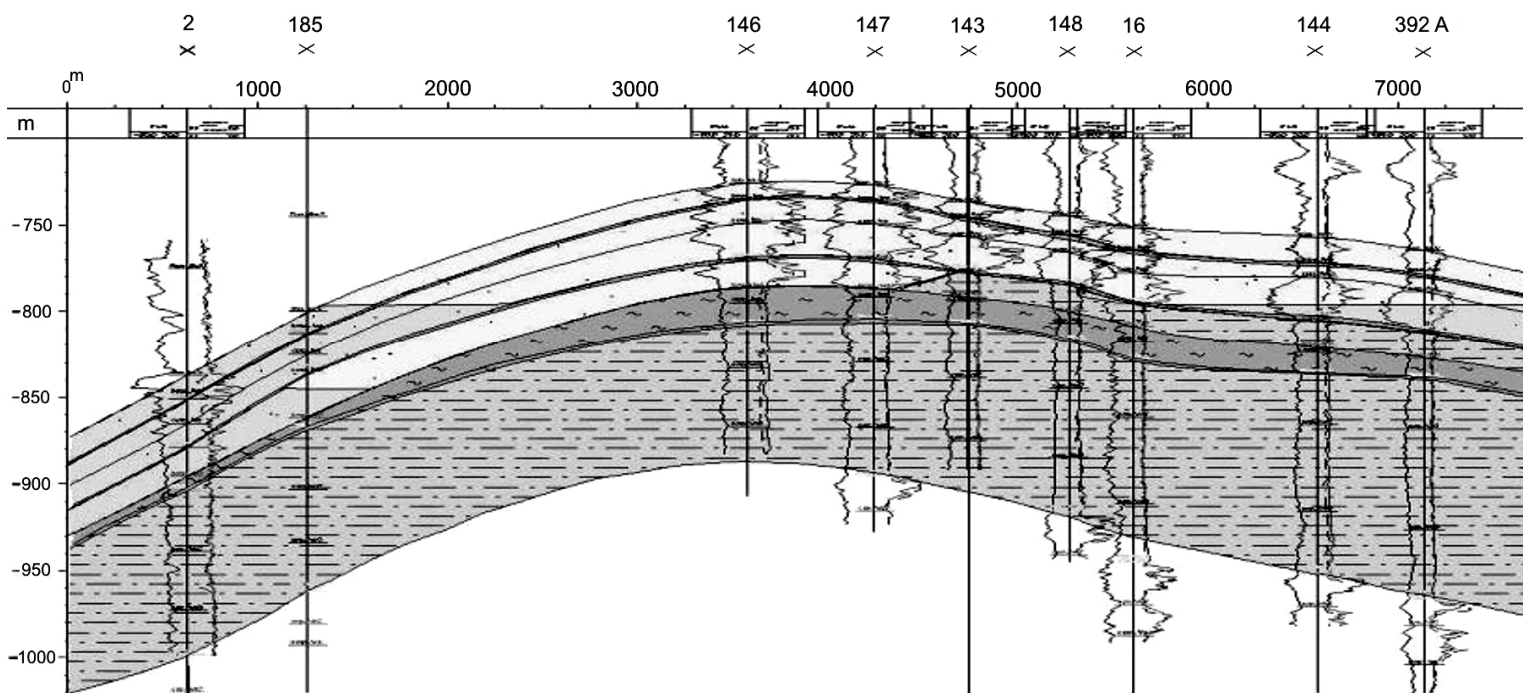

Fig. 3. Cross-section from a Transylvanian UGS.

Before constructing an UGS deposit all the geological and production data have to be revised and analyzed and, if necessary, more investigations have to be done. Needed geological investigations are: seismic surveys, petrophysical data and analyses, core data and analyses, geophysical investigations in the wells, fluid analyses.

Acknowledgements. I would like to express my thanks to Alin Igritan for helping me to redrawn the figures.

\section{R E F E R E N C E S}

Grigoraş, D. 2002, Depozitarea fluidelor. Ed. Universităţii, Ploieşti, 169 pp.

C.C.I.T.G.M., Romgaz R.A. 1996, Studiu de prefezabilitate privind transformarea zăcământului Sm VI Sărmăssel in depozit de înmagazinare gaze şi reevaluarea capacității la obiectivul Bgl. VII, in funcție de informațiile obținute după primul ciclu complet de inmagazinareextracție. Mediaş.

S.C. Amgaz S.A. 2004, Analiza posibilitătilor de efectuare in perioada 2004-2006 a unor procese limitate de inmagazinare gaze în zăcământul Sm VII din câmpul gazeifer Nadeş-Prod-Seleuş. Studiu de soluție. Mediaş.

S.C. Gaz Consult S.A. 2005, Studiu privind mărirea capacității de înmagazinare gaze în zăcământul Bălăceanca, prin includerea structurii de la Postăvari. Mediaş.

S.N.G.N. Romgaz S.A. 1998, Analiza lucrărilor şi investitiilor suplimentare necesare pentru realizarea capacității de $1050 \mathrm{mil}$. mc/ciclu prevăzută în studiul de fezabilitate şi a creşterii parametrilor de performanță pentru depozitul Bilciureşti. Mediaş.

S.N.G.N. Romgaz S.A. 2001, Studiu privind dezvoltarea capacității de înmagazinare subterană a gazelor naturale în zăcământul Sm IV+Va Târgu-Mureş. Mediaş.

S.N.G.N. Romgaz S.A. 2003, Studiu de fezabilitate privind amenajarea unui depozit subteran de gaze în câmpul gazeifer Gherceşti, jud Dolj (capacitate 600 mil.mc/ciclu). Mediaş.

S.N.G.N. Romgaz S.A. 2005, Studiu privind mărirea capacității de inmagazinare subterană a gazelor în câmpul gazeifer Urziceni, la 300 mil. mc/ciclu. Mediaş. 